\title{
New resolving bases for ibuprofen and mandelic acid: qualification by binary phase diagrams
}

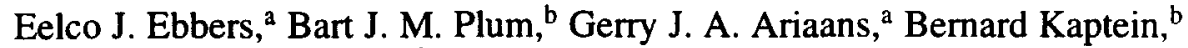 \\ Quirinus B. Broxterman, ${ }^{b}$ Alle Bruggink ${ }^{\star a, c}$ and Binne Zwanenburg ${ }^{\star a, *}$ \\ a Department of Organic Chemistry, NSR-Center for Molecular Structure, Design and Synthesis, \\ University of Nijmegen, Toernooiveld, 6525 ED Nijmegen, The Netherlands \\ b DSM Research, Organic Chemistry and Biotechnology Section, P.O. Box 18, 6160 MD Geleen, \\ The Netherlands \\ ' Chemferm, De Bijster 18, 4800 DX Breda, The Netherlands
}

\begin{abstract}
New resolving bases for ibuprofen 1 and mandelic acid 2 were studied and qualified by their binary phase diagrams of the corresponding salts. It was shown that analysis of the binary phase diagrams gives a good prediction for a resolution process. A comparison of resolving bases revealed that (S)-phenylglycinol (S)-7 is the best resolving base for ibuprofen 1. By the same procedure, various resolving bases for mandelic acid 2 were studied. The known resolving base (S)-MBA 9 was found to be the best for this acid. (C) 1997 Elsevier Science Ltd. All rights reserved.
\end{abstract}

\section{Introduction}

Resolution of enantiomers is an important method for the industrial production of enantiopure compounds. The most frequently applied method is formation and selective crystallization of diastereomeric salts. The major problem of this approach is identifying a suitable resolving agent. Until now, no suitable method is available to predict a resolving agent for a given racemate. ${ }^{1}$ The conditions required for an efficient resolution are: the diastereomeric salts consist of a mechanical mixture of crystals of the pure diastereomers (eutectic mixture); both salt pairs can be crystallized separately and have substantial differences in physico-chemical properties, especially solubilities. ${ }^{2}$

Optimum conditions (e.g. concentration, temperature) for a resolution process can be quantified by construction of the ternary (solubility) phase diagram. However, this requires a large amount of experimental data. It is a well known fact that binary (melting) phase diagrams are often a good approximation for ternary diagrams especially for selection and qualification of a resolving agent for a given substrate. ${ }^{3,4}$ Thus, the efficiency of a resolution depends on the location of the eutectic. The formation or existence of a eutectic mixture, a primary condition for a resolution, can be determined. Moreover, the diagram allows calculation of the maximum yield $\left(R_{\max }\right)$ and efficiency ${ }^{5}(S)$. Starting from the racemic composition $\left(x_{0.5}\right)$ and going to the isolation of a pure diastereomer, the following equations can be used to calculate these parameters: ${ }^{6}$

$R_{\max }=\frac{0.5-x_{\mathrm{eu}}}{1-x_{\mathrm{eu}}} \times 100 \% \quad\left(R_{\max }=0-50 \%\right)$

$S=k t=\frac{1-2 x_{\mathrm{eu}}}{1-x_{\mathrm{eu}}} \quad(S=0-1)$

where $x$ is the molar fraction of the less soluble diastereomer, $x_{\mathrm{eu}}$ the eutectic composition, $k$ the chemical yield ( $k=2$ for $100 \%$ ) and $t$ the optical purity ( $t=1$ for $100 \%$ ee). A more successful resolution is expected when the diagram has a steeper slope, i.e. a larger difference between the melting points

\footnotetext{
* Corresponding author. Email: zwanenb@sci.kun.nl
} 
<smiles>CC(C)Cc1ccc(C(C)C(=O)O)cc1</smiles>

1<smiles>O=C(O)C(O)c1ccccc1</smiles>

2<smiles>CC[C@H](N)COCc1ccccc1</smiles>

(S)-3<smiles>[R]N(C)[C@H]([C@H](C)O)[C@H](O)c1ccccc1</smiles>

$(-)-\mathbf{b}(\mathrm{R}=\mathrm{Me})$

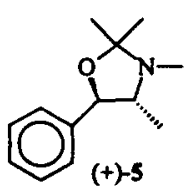

$(+)-5$<smiles>Cc1ccc(CC(N)c2ccccc2)cc1</smiles><smiles>N[C@@H](CO)c1ccccc1</smiles><smiles>CC(CN(C)C)C(O)(Cc1ccccc1)c1ccccc1</smiles><smiles>CC(N)c1ccccc1</smiles>

Figure 1. Substrates and resolving bases.

of the pure diastereomers and a more eccentric eutectic. The binary phase diagram of a diastereomeric mixture can be constructed using the Schröder-van Laar equation. ${ }^{4}$

The use of binary phase diagrams for qualification and selection of resolving agents also has some limitations, i.e. diagrams cannot be constructed when thermal decomposition takes place, the role of solvates cannot be observed and both diastereomers are not always available.

Using this approach, five new resolving bases for ibuprofen 1 have been tested, (S)-1-(benzyloxymethyl)propylamine (BOP) (S)-3, (-)-ephedrine (-)-4a, (4S,5R)-(+)-1,2,5,5-2,2,3,4-tetramethyl5-phenyl-1,3-oxazolidine (TPO) (+)-5, (R)-1-phenyl-2-p-tolylethylamine (PTEA) (R)-6 and (S)phenylglycinol (S)-7. Also two new resolving bases for mandelic acid 2 were tried, (-)-Nmethylephedrine (-)-4b and (+)-(2S,3R)-4-dimethylamino-3-methyl-1,2-diphenyl-2-butanol (DMDB) (+)-8 (Figure 1).

Binary phase diagrams of these ibuprofenates and mandelates were constructed using differential scanning calorimetry (DSC). Experimental data are compared with calculated diagrams using the Schröder-van Laar equation. The diagrams were then used for the qualification of resolving bases for the given substrate. Known resolving agents with well-described physico-chemical data are also included.

\section{Results and discussion}

\section{Ibuprofen}

According to known methods, ibuprofen 1 can be resolved using either $\alpha$-methylbenzylamine $(\mathrm{MBA})^{7} 9$ or lysine. $^{8}$ The binary phase diagram of the ibuprofen $\cdot$ MBA salt 10 has not been reported previously. Therefore, this diagram was constructed revealing a eutectic mixture (Figure 2A). Several of the salt mixtures used to construct this diagram were analyzed by NMR and subjected to elemental analysis. There were no indications for the occurrence of solvates. Both the eutectic point $\left(x_{\mathrm{eu}}=0.66\right)$ and the flat slope are rather unfavorable for a good resolution process. The calculated maximum yield of enantiopure (S)-9 is limited to $24 \%$ starting from the racemic composition. Resolution according to a patent of Ethyl ${ }^{7 \mathrm{a}}$ confirmed the expected limitations.

Lysine is an interesting resolving base because ibuprofen 1 can be marketed as lysinate salt 11. The phase diagram of this lysinate 11 could not be constructed as no clear melting behavior of these salts was observed during the DSC experiments. From NMR, DSC and elemental analysis it was concluded that a solvate of salt 11 was formed with 0.5 equiv. of water. Resolution experiments ${ }^{8}$ indicated an efficiency $\left(S_{\text {exp }}\right)$ of $0.5-0.6$.

The binary phase diagram of ibuprofen-(S)-BOP salt 12 is shown in Figure 2B. The conglomerate has an unfavorable eutectic point $\left(x_{\mathrm{eu}}=0.33\right)$ which results in a low maximum yield and efficiency of $25 \%$ and 0.5 respectively. Moreover, the small difference between the melting points of the pure diastereomers results in a flat slope and will make a resolution process difficult, which was confirmed by some attempted resolution experiments. Several other 2-amino-1-butanols were investigated but all formed oily ibuprofenates. 
<smiles>CC(C)Cc1ccc(C(C)C(=O)O[Na])cc1</smiles>

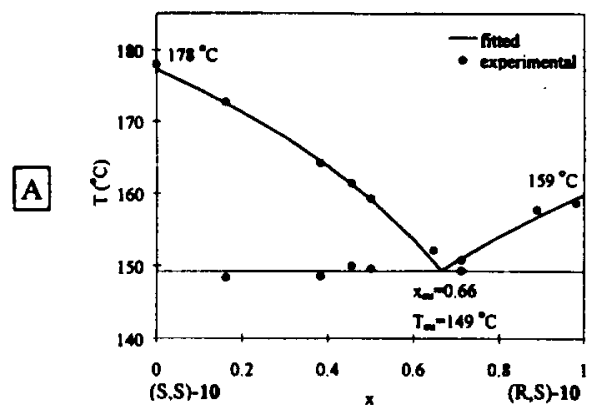<smiles></smiles>

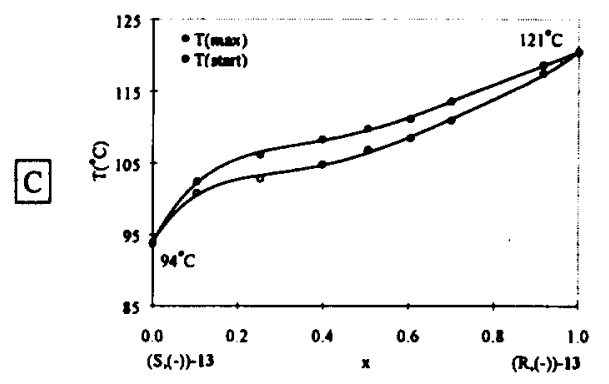<smiles>CC[C@H](N)COCc1ccccc1</smiles>

B
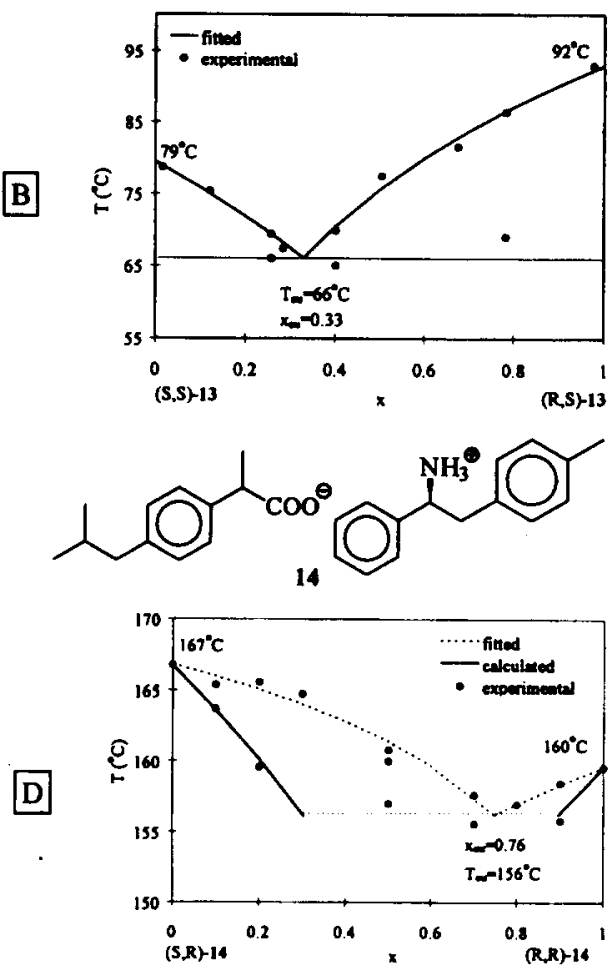<smiles>CC(C)Cc1ccc(C(C)C(=O)[O-])cc1</smiles>

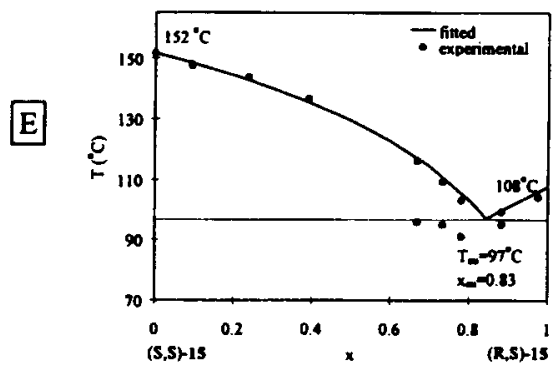

Figure 2. Binary phase diagrams of ibuprofen.

With (-)-ephedrine (-)-4a as a resolving agent the formation of crystalline salt with ibuprofen 1 was achieved. However, this ibuprofenate 13 was not suitable for the resolution of ibuprofen because it exists as a solid solution (Figure $2 \mathrm{C}$ ) as was deduced from thermograms which showed a single broad peak. A few resolution experiments using (-)-ephedrine (-)-4 in various solvents (e.g. toluene, diisopropyl ether) confirmed the formation of a solid solution as only low des and low yields could be obtained. Several substituted ephedrines were also studied, however all of them failed to crystallize. 
Table 1. Resolving agents for ibuprofen 1 and their resolving abilities ${ }^{\mathbf{a}}$

\begin{tabular}{cccccccccc}
\hline Salt & Type & $\begin{array}{c}\Delta \mathrm{H}_{\text {exp }} \\
(\mathrm{kJ} / \mathrm{mole})\end{array}$ & $\begin{array}{c}\Delta \mathrm{H}_{\text {calc }} \\
(\mathrm{kJ} / \mathrm{mole})\end{array}$ & $\begin{array}{c}\mathrm{T}_{\exp } \\
\left({ }^{\circ} \mathrm{C}\right)\end{array}$ & $\begin{array}{c}\mathrm{T}_{\text {calc }} \\
\left({ }^{\circ} \mathrm{C}\right)\end{array}$ & $\begin{array}{c}\mathrm{T}_{\text {eu }} \\
\left({ }^{\circ} \mathrm{C}\right)\end{array}$ & $\mathrm{x}_{\text {eu }}$ & $\begin{array}{c}\mathrm{R}_{\max } \\
(\%)\end{array}$ & $\mathrm{S}_{\text {calc }}$ \\
\hline (S,S)-10 & conglomerate & 59.8 & 61.8 & 178 & 178 & 149 & 0.66 & 24 & 0.48 \\
(R,S)-10 & & 52.9 & 58.8 & 159 & 159 & 149 & & & \\
lysinate 11 & solvate & & & & & & & & $0.5-0.6^{8}$ \\
$(\mathrm{~S}, \mathrm{~S})-12$ & conglomerate & 30.0 & 29.7 & 80 & 79 & 66 & 0.33 & 25 & 0.51 \\
$(\mathrm{R}, \mathrm{S})-12$ & & 37.4 & 42.6 & 93 & 93 & & & & \\
$(\mathrm{~S},(-))-13$ & solid solution & 38.5 & & 94 & & & & & \\
$(\mathrm{R},(-))-13$ & & 41.5 & & 121 & & & & & \\
$(\mathrm{~S}, \mathrm{R})-14$ & partial solid solution $/$ & 53.5 & & 167 & & & & & \\
& conglomerate & & & & & & & & \\
$(\mathrm{R}, \mathrm{R})-14$ & & 50.9 & & 160 & & & & \\
$(\mathrm{~S}, \mathrm{~S})-15$ & conglomerate & 44.4 & 44.2 & 152 & 152 & 97 & 0.83 & 40 & 0.80 \\
$(\mathrm{R}, \mathrm{S})-15$ & & 20.1 & 18.5 & 104 & 108 & & & & \\
\hline
\end{tabular}

$\Delta H_{\text {exp }}$ is the experimental heat of fusion, $T_{\text {exp }}$ the experimental melting point, $\Delta H_{c a l c}$ and $T_{c a l c}$ are the calculated values by the Schröder-van Laar equation (5-3), $T_{e v}$ and $x_{e u}$ were determined using the calculated phase diagram, the maximum yield $\left(R_{\max }\right)$ and efficiency $(S)$ were calculated using equations 5-1, 5-2 and $x_{\text {eut }}$.

Oxazolidine (+)-5 derived from (-)-ephedrine did produce crystalline salts with ibuprofen 1, but these salts decomposed during resolution experiments even at room temperature.

Several substituted $\mathrm{MBAs}^{\dagger}$ were studied as potential resolving agents. Only (R)-PTEA (R)-6 gave a crystalline ibuprofenate 14. Constructing the phase diagram of ibuprofenate 14 results in a relatively rare diagram (Figure 2D). Diastereomeric salt mixtures 14 were analyzed by NMR and elemental analysis showing salts in a 1:1 ratio without the inclusion of solvent. Consequently, this diagram is best typified as a solid solution between crystalline diastereomeric salts existing as conglomerates. ${ }^{9}$ The diagram does not represent a complete solid solution because no broad single peaks were observed. Most thermograms showed two overlapping peaks, which could be separated using peakfitting calculations ${ }^{10}$ in some cases. The possibility of the formation of a (1:1) double salt was rejected due to the absence of the typical maximum at $x=0.5 .{ }^{11}$ The use of PTEA 6 as a resolving agent for ibuprofen 1 was abandoned because of the above behavior of this ibuprofenate.

Finally, (S)-phenylglycinol (S)-7 was studied as a possible resolving agent for ibuprofen 1 . The melting diagram (Figure 2E) of the ibuprofenate salt 15 indicated the formation of a diastereomeric mixture with a favorable eutectic composition, moreover the diagram has a steep slope. The calculated diagram based on the pure diastereomers is in full agreement with the experimental results. Hence, phenylglycinol 7 can be qualified as a potentially suitable resolving base for ibuprofen 1 . Based on the eutectic point $\left(x_{\mathrm{eu}}=0.83\right)$ a resolution with a maximum yield of $40 \%$ and efficiency of 0.8 is possible. Resolution experiments of ibuprofen 1 with (S)-phenylglycinol (S)-7 in acetone or toluene/hexane mixtures resulted in the isolation of (S,S)-15 as crystalline salt with des up to 53\%, yields above 50\% and efficiencies of about 0.5 . Several other substituted phenylglycinols were synthesized but all of them formed oily ibuprofenates.

The results of the various resolving bases investigated for ibuprofen 1 are summarized in Table 1 showing phenylglycinol 7 as the most promising resolving agent for ibuprofen 1 . Currently, phenylglycinol 7 is further developed as a resolving base for ibuprofen 1.

\section{Mandelic acid}

Mandelic acid 2 is a widely applied resolving agent for various amines. ${ }^{12}$ Both antipodes are commercially available at low prices in enantiopure form. ${ }^{13}$ Physico-chemically well-studied

†nantiopure substituted MBAs $N$-(p-hydroxybenzyl)-1-(R)-p-tolyl-ethylamine, 1-(R)-phenyl-2-p-tolylethylamine (R)-6 and $N$-(p-methoxy-o-hydroxybenzyl)-1-(R)-p-tolyl-ethylamine were kind gifts from Sumitomo Chemical Company, Ltd, Japan. 


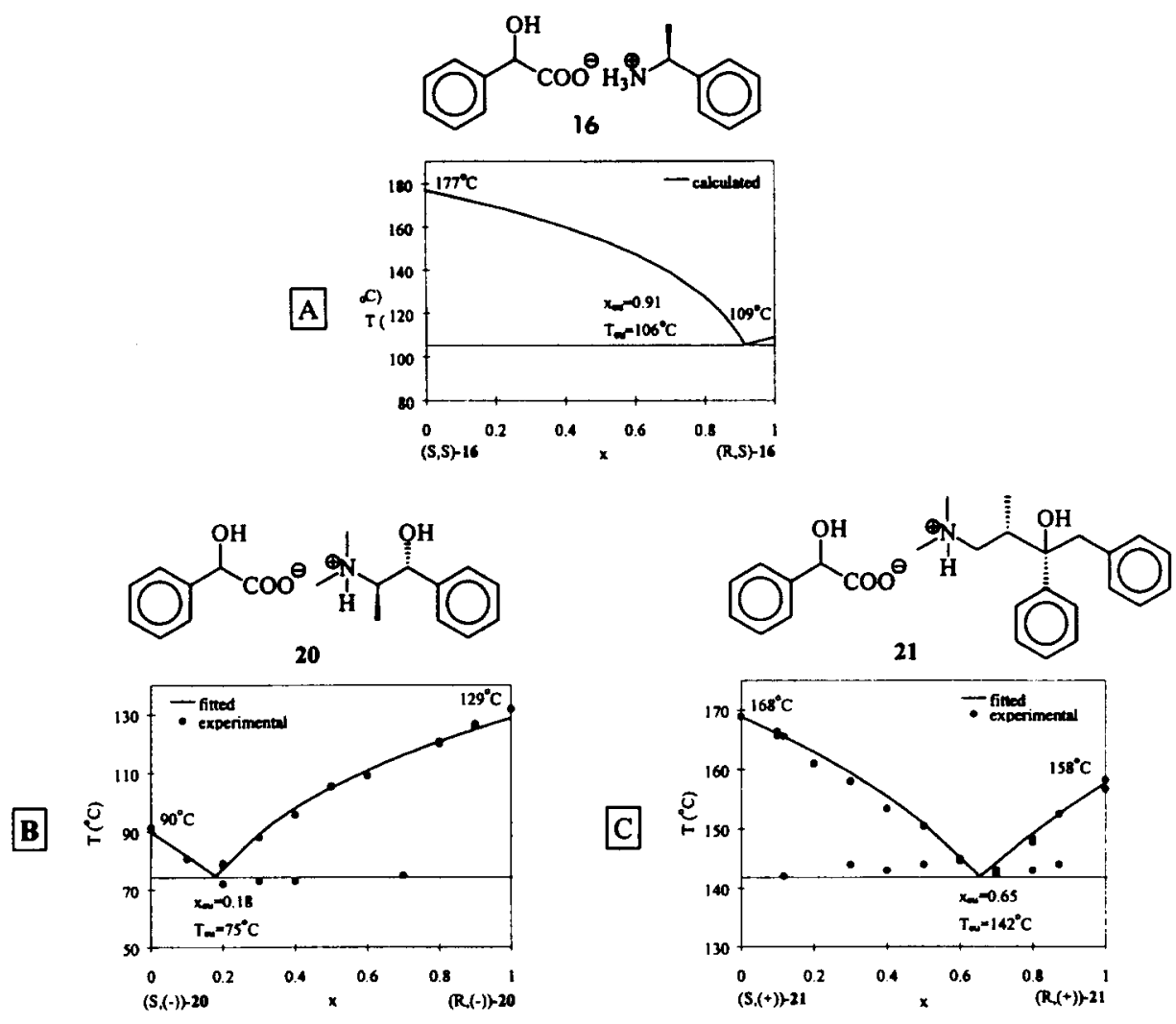

Figure 3. Binary phase diagrams of mandelates.

mandelate salts used for resolution purposes are MBA mandelate 16 (Figure 3A), ${ }^{14}$ 2-benzylamino1-butanol mandelate 17, ${ }^{3.15}$ (R)-2-tert-butyl-3-methylimidazolidin-4-one (BMI) mandelate 18 $^{3,16}$ and (+)-cinchonine mandelate 19. ${ }^{17}$ Other known resolving agents are brucine, ${ }^{18}$ quinine,${ }^{18}$ quinidine, ${ }^{18}$ (-)-ephedrine, ${ }^{19}(-)$-2-amino-1-butanol, ${ }^{20}$ amphetamine ${ }^{14 \mathrm{c}}$ and adrenaline. ${ }^{14 \mathrm{c}}$

Two new resolving bases (-)- $N$-methylephedrine (-)-4b and (+)-DMDB (+)-8, formed crystalline mandelates 20 and 21 respectively. Their resolving ability was studied by their binary phase diagrams which showed the formation of eutectic mixtures (Figure 3B and 3C). The physico-chemical properties of these mixtures are summarized in Table 2 and were compared with known mandelates 16-19. The experimental results of mandelates 20 and 21 are in good agreement with the calculated diagrams. However, two deviations were observed when comparing the experimental and calculated heats of fusion of $(\mathrm{S},(-))-20$ and $(\mathrm{R},(+))-21$. In both cases a difference of about $15 \mathrm{~kJ} / \mathrm{mol}$ was observed. This may imply that the simplified Schröder-van Laar equation is not valid for these sections of the diagrams. This deviation may be attributed to several effects, e.g. the specific heat capacities of the pure diastereomers cannot be neglected, the mixtures of diastereomers do not show ideal behavior in the solid or liquid phase, polymorphism or incongruent melting. ${ }^{21}$

The results in Table 2 clearly reveal MBA 9 as the most appropriate resolving base for mandelic acid 2 (Figure 3A). The eutectic composition of the corresponding mandelate salt 16 lies toward the end of the diagram resulting in an almost ideal efficiency and yield. Moreover, the large difference between the melting points of the pure salts results in a steep slope of the diagram. Also, both enantiomers of MBA 9 are readily available at the same price allowing straightforward preparation of either enantiomer of mandelic acid 2. Only when the primary amine MBA 9 is not preferred (for example because of amide formation) tertiary amines (-)-N-methylephedrine (-)-4b and BMI 18 are good alternatives. 
Table 2. Resolving agents for mandelic acid 2 and their resolving abilities ${ }^{\mathrm{a}}$

\begin{tabular}{|c|c|c|c|c|c|c|c|c|c|c|}
\hline Salt & Type & $\underset{(\mathrm{kJ} / \text { mole })}{\Delta \mathrm{H}_{\exp }}$ & $\begin{array}{c}\Delta \mathrm{H}_{\text {calc }} \\
(\mathrm{kJ} / \mathrm{mole})\end{array}$ & $\begin{array}{l}\mathrm{T}_{\exp } \\
\left({ }^{\circ} \mathrm{C}\right)\end{array}$ & $\begin{array}{l}\mathrm{T}_{\text {calc }} \\
\left({ }^{\circ} \mathrm{C}\right)\end{array}$ & $\begin{array}{l}T_{\text {eu }} \\
\left({ }^{\circ} \mathrm{C}\right)\end{array}$ & $x_{\text {eu }}$ & $\begin{array}{l}R_{\max } \\
(\%)\end{array}$ & $S_{\text {calc }}$ & $S_{\text {exp }}$ \\
\hline$(\mathrm{S}, \mathrm{S})-16^{3}$ & conglomerate & 48.9 & & 177 & 106 & 108 & 0.09 & 45 & 0.9 & 0.86 \\
\hline$(\mathrm{R}, \mathrm{S})-16$ & & 30.3 & & 109 & & & & & & \\
\hline (p) $-17^{3}$ & conglomerate & 32.1 & & 108 & & 69 & 0.32 & 26 & 0.45 & 0.32 \\
\hline (n)-17 & & 28.8 & & 84 & & & & & & \\
\hline$(R, R)-18^{3}$ & conglomerate & 51.5 & & 118 & & 76 & 0.15 & 41 & 0.82 & 0.82 \\
\hline$(S, R)-18$ & & 30.6 & & 79 & & & & & & \\
\hline 19 & solvate & & & & & & & & $0.3-0.5$ & \\
\hline$(S,(-))-20$ & conglomerate & 30.0 & 13.5 & 91 & 90 & 75 & 0.18 & 39 & 0.78 & \\
\hline$(R,(-))-20$ & & 40.9 & 36.9 & 132 & 129 & & & & & \\
\hline$(\mathrm{S},(+))-21$ & conglomerate & 59.2 & 60.0 & 169 & 168 & 142 & 0.65 & 23 & 0.46 & \\
\hline$(R,(+))-21$ & & 55.9 & 40.0 & 158 & 158 & & & & & \\
\hline
\end{tabular}

a) $\Delta \mathrm{H}_{\text {exp }}$ is the experimental heat of fusion, $T_{\text {exp }}$ the experimental melting point and $S_{\text {exp }}$ the experimental efficiency, $\Delta H_{\text {calc }}$ and $T_{c a k}$ are the calculated values by the Schroder-van Laar equation, $T_{e u}$ and $x_{\text {eat }}$ were determined by using the calculated phase diagram, the maximum yield $\left(R_{\max }\right)$ and efficiency $\left(S_{c a l c}\right)$ were calculated by equations $5-1,5-2$ and $x_{\text {ou. }}$.

\section{Experimental}

${ }^{1} \mathrm{H}-\mathrm{NMR}$ spectra were recorded on a Bruker AC-100 (100 MHz, FT) spectrometer with tetramethylsilane as internal standard. IR spectra were recorded on a Perkin-Elmer 298 spectrophotometer or Perkin-Elmer FTIR 1720-X spectrophotometer. Elemental analyses were performed with a Carlo Erba CHNSO 1108 elemental analyzer. For mass spectroscopy, a double focusing VG 7070E was used. For the chemical ionization $(\mathrm{CI})$ technique, methane was used as the reacting gas. Melting points were measured on a Reichert Thermopan microscope (uncorrected) or on a Perkin-Elmer DSC7 instrument. Optical rotations were determined on a Perkin-Elmer 241 polarimeter at $589 \mathrm{~nm}$, equipped with a quartz cell of $1.00 \mathrm{dm}$ path length. The polarimeter was connected with a thermostat for exact temperature control. For column chromatography, the 'flash technique'22 was used with silica gel $60 \mathrm{H}$ (Merck) as the stationary phase and a pressure of about 1.5 bar. Tetrahydrofuran was distilled from lithium aluminum hydride. All other solvents and reagents were either p.a. or 'reinst' quality and used as obtained from the supplier.

Racemic and enantiopure (S)-ibuprofen was a gift from DSM Andeno, Venlo, The Netherlands. (R)ibuprofen was prepared by purification of diastereomerically enriched (R)-ibuprofen $\cdot(R)-M B A$ salt $^{7 a}$ or (R)-ibuprofen sodium salt. ${ }^{23}$ The chiral bases $N$-( $p$-hydroxybenzyl)-1-(R)-p-tolyl-ethylamine, 1 (R)-phenyl-2-p-tolyl-ethylamine and $N$-( $p$-methoxy-o-hydroxybenzyl)-1-(R)-p-tolyl-ethylamine were a gift from Sumitomo Chemical Co. Ltd, Japan.

Enantiomeric excesses of ibuprofen and mandelic acid were determined using chiral HPLC (performed on a Spectra Physics HPLC system equipped with a chiral Daicel Chiralcel ODH column, $25 \times 0.46 \mathrm{~cm}$, particle size: $5 \mu \mathrm{m}$, ambient temperature): ibuprofen (eluent: hexane:2-propanol:trifluoroacetic acid=980:20:2.5, v/v), mandelic acid (eluent: hexane:2propanol:trifluoroacetic acid=875:125:2.5, v/v).

DSC thermograms were determined using a Perkin-Elmer DSC7 instrument, calibrated with In and $\mathrm{Zn}$ or $\mathrm{Sn}$. Samples (2-10 mg) were weighed with an accuracy of $0.01 \mathrm{mg}$ and encapsulated in stainless steel large volume pans $(75 \mu \mathrm{l})$. Thermograms were recorded at a scanning rate of $10^{\circ} \mathrm{C} / \mathrm{min}$, a data rate of $0.4-0.8 \mathrm{sec} /$ point and with an empty pan as reference under a nitrogen atmosphere. Melting points are given as the top of the peaks because of broad peaks. If necessary, deconvolution of peaks was performed using PeakFit ${ }^{\infty}$ version 4 for Win32 (Jandel Scientific Software). Pearson IV peaks were used as the peak description. Solid solution diagrams were constructed using the beginning and maximum of the broad peaks for the solidus and liquidus curves, respectively. The start temperature for 
melting mixtures of diastereomers was corrected with the width of the peaks of the pure diastereomers $\left(\mathrm{T}_{\max }-\mathrm{T}_{\text {start }}\right)$.

\section{Preparation of salts}

Pure diastereomeric salts were prepared by mixing equimolar amounts of enantiopure base and acid 1 or 2 in ethanol. The salts obtained were allowed to crystallize, filtered and dried in vacuo.

Diastereomeric salt mixtures were prepared as described by Jacques, Collet and Wilen. ${ }^{24}$ Accurately weighed amounts of the pure salts were dissolved in ethanol and the solution obtained was concentrated and dried in vacuo. The composition of mixtures obtained were analyzed by chiral HPLC on liberated ibuprofen 1 or mandelic acid 2.

\section{Hydrolysis of ibuprofen and mandelic acid salts (general procedure)}

Ibuprofenates were hydrolyzed with $1 \mathrm{~N}$ aqueous sulfuric acid at $\mathrm{pH} 1-2$, stirred for $0.5 \mathrm{~h}$ at room temperature and extracted with dichloromethane (three times). The combined organic layers were extracted with brine, dried over $\mathrm{MgSO}_{4}$ and concentrated in vacuo to give ibuprofen 1 .

Mandelates were hydrolyzed with $2 \mathrm{~N}$ aqueous hydrochloric acid at $\mathrm{pH} \mathrm{1-2,} \mathrm{stirred} \mathrm{for} 0.5 \mathrm{~h}$ at room temperature and extracted with ethyl acetate (three times). The combined organic layers were extracted with brine, dried over $\mathrm{MgSO}_{4}$ and concentrated in vacuo to give mandelic acid 2.

\section{(S)-1-(Benzyloxymethyl)propylamine (S)-3}

Amine (S)-3 was prepared using the Williamson reaction. ${ }^{25}$ To a slurry of sodium hydride $(6.6 \mathrm{~g}$, $120 \mathrm{mmol})$ in dry tetrahydrofuran $(50 \mathrm{ml})$ under a nitrogen atmosphere, (S)-2-amino-1-butanol (10.0 $\mathrm{g}, 110 \mathrm{mmol}$ ) was gradually added. The mixture was stirred for $17 \mathrm{~h}$ at $80^{\circ} \mathrm{C}$ and then a solution of benzylchloride $(15.6 \mathrm{~g}, 250 \mathrm{mmol})$ in dry tetrahydrofuran $(100 \mathrm{ml})$ was added dropwise. The resulting solution was stirred for $20 \mathrm{~h}$ at $70^{\circ} \mathrm{C}$ and subsequently cooled to room temperature. Ethyl acetate ( 100 $\mathrm{ml})$, methanol $(100 \mathrm{ml})$ and water $(100 \mathrm{ml})$ were added and the resulting solution was concentrated to a volume of about $100 \mathrm{ml}$. Water $(200 \mathrm{ml})$ was added, the mixture was acidified to $\mathrm{pH} 1-2$ and extracted twice with dichloromethane. The water layer was treated with sodium hydrogen carbonate until pH 11-12 and extracted with dichloromethane (three times). The combined organic layers were dried over $\mathrm{MgSO}_{4}$ and concentrated in vacuo to give pure (S)-3 as an oil $(15.2 \mathrm{~g}, 77 \%)$. $[\alpha]_{\mathrm{D}}{ }^{25}-18.1$ (methanol, c=1.0). IR $\left(\mathrm{CCl}_{4}, \mathrm{~cm}^{-1}\right): \vee 3400-2800(\mathrm{NH}), 1100(\mathrm{C}-\mathrm{O}) .{ }^{1} \mathrm{H}-\mathrm{NMR}\left(\mathrm{CDCl}_{3}, \mathrm{ppm}\right): \delta$ 0.85 (t, 3H, $\left.\mathrm{CH}_{3} \mathrm{CH}_{2}, \mathrm{~J}=7.0 \mathrm{~Hz}\right), 1.0-1.8\left(\mathrm{~m}, 4 \mathrm{H}, \mathrm{CH}_{2} \mathrm{CH}_{3}, \mathrm{NH} \mathrm{H}_{2}\right) 2.8-3.0(\mathrm{~m}, 1 \mathrm{H}, \mathrm{CH}), 3.1-3.5(\mathrm{~m}$, $2 \mathrm{H}, \mathrm{OCH}_{2} \mathrm{CH}$ ), $4.52\left(\mathrm{~s}, 2 \mathrm{H}, \mathrm{OCH}_{2} \mathrm{Ar}\right), 7.1-7.4(\mathrm{~m}, 5 \mathrm{H}, \mathrm{Ar} H)$. Literature: ${ }^{26}[\alpha]_{\mathrm{D}}{ }^{25}-15.7$ and -18.9 (ethanol, $c=1.5$ ), IR and ${ }^{1} \mathrm{H}-\mathrm{NMR}$ were identical with those described above.

\section{(4S,5R)-2,2,3,4-Tetramethyl-5-phenyl-oxazolidine (+)-(4S,5R)-5}

A solution of (-)-ephedrine $4 \mathrm{a}(24 \mathrm{~g}, 140 \mathrm{mmol})$ and $p$-toluenesulfonic acid $(2.5 \mathrm{~g}, 14 \mathrm{mmol})$ in a mixture of chloroform $(100 \mathrm{ml})$ and 2,2-dimethoxypropane $(90 \mathrm{ml}, 700 \mathrm{mmol})$ was refluxed for one week. The mixture was then cooled to room temperature, concentrated and dissolved in dichloromethane $(100 \mathrm{ml})$. This solution was extracted twice with $1 \mathrm{~N}$ aqueous sodium hydroxide and concentrated in vacuo. The product was purified by column chromatography (flash, silica gel $60 \mathrm{H}$, dichloromethane:methanol: $\mathrm{Et}_{3} \mathrm{~N}=600: 100: 2$, v/v) to give pure (+)-(4S,5R)-5 (4.4 g, 15\%). Mp $40-42^{\circ} \mathrm{C},[\alpha]_{\mathrm{D}}{ }^{25}+17.7$ (ethanol, $\mathrm{c}=1.0$ ). Literature: ${ }^{27} \mathrm{Mp} 39-43^{\circ} \mathrm{C},[\alpha]_{\mathrm{D}}{ }^{25}+22.0$ (ethanol). Calculated for $\mathrm{C}_{13} \mathrm{H}_{19} \mathrm{NO}: 76.06 \% \mathrm{C}, 9.33 \% \mathrm{H}, 6.82 \% \mathrm{~N}$; found: $75.76 \% \mathrm{C}, 9.19 \% \mathrm{H}, 6.88 \% \mathrm{~N}$. ' $\mathrm{H}-\mathrm{NMR}$ $\left(\mathrm{CDCl}_{3}, \mathrm{ppm}\right): \delta 0.63\left(\mathrm{~d}, 3 \mathrm{H}, \mathrm{CH}_{3} \mathrm{CH}, \mathrm{J}=6.4 \mathrm{~Hz}\right), 1.21\left(\mathrm{~s}, 3 \mathrm{H}, \mathrm{CH}_{3} \mathrm{C}\right), 1.52\left(\mathrm{~s}, 3 \mathrm{H}, \mathrm{CH}_{3} \mathrm{C}\right), 2.26(\mathrm{~s}$, $\left.3 \mathrm{H}, \mathrm{CH}_{3} \mathrm{~N}\right), 3.14(\mathrm{dq}, 1 \mathrm{H}, \mathrm{CHN}, \mathrm{J}=6.4,8.0 \mathrm{~Hz}), 5.03(\mathrm{~d}, 1 \mathrm{H}, \mathrm{CHO}, \mathrm{J}=8.0 \mathrm{~Hz}), 7.2-7.4(\mathrm{~m}, 5 \mathrm{H}, \mathrm{ArH})$. MS (EI): m/e (\%) $206\left(\mathrm{M}^{+}+1,18\right), 190\left(\mathrm{M}^{+}-\mathrm{Me}, 33\right), 148$ (206-acetone, 100), 133 (148-Me, 6).

\section{Ibuprofen $\cdot(S)$ - $\alpha$-methylbenzylamine salt 10}

(S,S)-10: $\mathrm{Mp} 178.0^{\circ} \mathrm{C},[\alpha]_{\mathrm{D}}{ }^{25}+0.89$ (ethanol, $\mathrm{c}=1.0$ ). Calculated for $\mathrm{C}_{21} \mathrm{H}_{29} \mathrm{NO}_{2}: 77.03 \% \mathrm{C}, 8.93 \%$ $\mathrm{H}, 4.28 \% \mathrm{~N}$; found: $76.77 \% \mathrm{C}, 8.84 \% \mathrm{H}, 4.37 \% \mathrm{~N}$. ${ }^{1} \mathrm{H}-\mathrm{NMR}\left(\mathrm{CDCl}_{3}, \mathrm{ppm}\right): \delta 0.87\left(\mathrm{~d}, 6 \mathrm{H},\left(\mathrm{CH}_{3}\right)_{2} \mathrm{CH}\right.$, 
$\mathrm{J}=6.5 \mathrm{~Hz}), 1.32$ and $1.35\left(2 \mathrm{~d}, 6 \mathrm{H}, \mathrm{CH}_{3} \mathrm{CHN}\right.$ and $\left.\mathrm{CH}_{3} \mathrm{CHCO}, \mathrm{J}=6.9 \mathrm{~Hz}\right), 1.6-1.9\left(\mathrm{~m}, 1 \mathrm{H}, \mathrm{CHCH}_{2}\right)$, $2.41\left(\mathrm{~d}, 2 \mathrm{H}, \mathrm{CH}_{2}, \mathrm{~J}=7.1 \mathrm{~Hz}\right), 3.48(\mathrm{q}, 1 \mathrm{H}, \mathrm{CHCO}, \mathrm{J}=7.0 \mathrm{~Hz}), 4.00(\mathrm{q}, 1 \mathrm{H}, \mathrm{CHN}, \mathrm{J}=6.9 \mathrm{~Hz}), 5.96(\mathrm{~s}$, $\left.3 \mathrm{H}, \mathrm{NH}_{3}{ }^{+}\right)$, 7.0-7.4 (m, 9H, ArH, ). IR (KBr, cm$\left.{ }^{-1}\right)$ : v 3100-2500, $2220(\mathrm{NH}), 1625,1545(\mathrm{C}=\mathrm{O})$.

(R,S)-10: Mp 158.6 ${ }^{\circ} \mathrm{C},[\alpha]_{\mathrm{D}}{ }^{25}-40.0$ (ethanol, $\mathrm{c}=0.1$ ). Calculated for $\mathrm{C}_{21} \mathrm{H}_{29} \mathrm{NO}_{2}: 77.03 \% \mathrm{C}, 8.93 \%$ $\mathrm{H}, 4.28 \% \mathrm{~N}$; found: $77.07 \% \mathrm{C}, 8.76 \% \mathrm{H}, 4.39 \% \mathrm{~N} .{ }^{1} \mathrm{H}-\mathrm{NMR}\left(\mathrm{CDCl}_{3}, \mathrm{ppm}\right): \delta 0.83\left(\mathrm{~d}, 6 \mathrm{H},\left(\mathrm{CH}_{3}\right)_{2} \mathrm{CH}\right.$, $\mathrm{J}=6.4 \mathrm{~Hz}), 1.32$ and $1.38\left(2 \mathrm{~d}, 6 \mathrm{H}, \mathrm{CH}_{3} \mathrm{CHCO}\right.$ and $\left.\mathrm{CH}_{3} \mathrm{CHN}, \mathrm{J}=6.9 \mathrm{~Hz}\right), 1.6-1.9\left(\mathrm{~m}, 1 \mathrm{H}, \mathrm{CHCH}_{2}\right)$, $2.38\left(\mathrm{~d}, 2 \mathrm{H}, \mathrm{CH}_{2}, \mathrm{~J}=7.1 \mathrm{~Hz}\right), 3.55(\mathrm{q}, 1 \mathrm{H}, \mathrm{CHCO}, \mathrm{J}=6.9 \mathrm{~Hz}), 4.02(\mathrm{q}, 1 \mathrm{H}, \mathrm{CHN}, \mathrm{J}=6.9 \mathrm{~Hz}), 5.04(\mathrm{~s}$, $\left.3 \mathrm{H}, \mathrm{NH}_{3}{ }^{+}\right), 7.0-7.4\left(\mathrm{~m}, 9 \mathrm{H}, \mathrm{Ar} H\right.$, ). IR $\left(\mathrm{KBr}, \mathrm{cm}^{-1}\right)$ : $\vee 3100-2300,2200(\mathrm{NH}), 1630,1550(\mathrm{C}=\mathrm{O})$.

\section{Resolution of ibuprofen I by (S)- $\alpha$-methylbenzylamine(S)-9}

Ibuprofen 1 was resolved following a procedure of Ethyl. ${ }^{7 a}$ Racemic ibuprofen (RS)-1 (1.03 g, $5.0 \mathrm{mmol})$ and triethylamine $(0.7 \mathrm{ml}, 5.0 \mathrm{mmol})$ were dissolved in octane $(1 \mathrm{ml})$ under a nitrogen atmosphere. The stirred mixture was heated to $125^{\circ} \mathrm{C}$ and to the clear solution obtained, (S)-MBA (S)-9 $(0.32 \mathrm{ml}, 2.5 \mathrm{mmol})$ was added dropwise. The white heterogeneous mixture was stirred for $3 \mathrm{~h}$ at $125^{\circ} \mathrm{C}$ and slowly cooled to room temperature. The precipitate was filtered off, washed with octane, dried in vacuo and weighed. A fraction of the salt was hydrolyzed and the ee of liberated ibuprofen 1 was analyzed by chiral HPLC. The principal part of the obtained salt was recrystallized twice from 2-propanol to give pure (S)-ibuprofen-(S)-MBA (S,S)-10 as white crystals $(0.6 \mathrm{~g}, 1.95 \mathrm{mmol})$ in $78 \%$ yield and with a de of $80.6 \%$. The ${ }^{1} \mathrm{H}-\mathrm{NMR}$ was in full accordance with 10 . The aforementioned patent claims the isolation of optically pure salt 10 in $69 \%$ yield after three crystallizations.

\section{(S)-Lysine ibuprofenate 11}

The salts were prepared according to the general procedure using a mixture of water:ethanol=95:5 $(\mathrm{v} / \mathrm{v})$ as the solvent.

(S,S)-11: Calculated for $\mathrm{C}_{19} \mathrm{H}_{32} \mathrm{~N}_{2} \mathrm{O}_{4} .0 .5 \mathrm{H}_{2} \mathrm{O}: 63.13 \% \mathrm{C}, 9.20 \% \mathrm{H}, 7.75 \% \mathrm{~N}$; found: $63.20 \% \mathrm{C}$, 9.06\% H, 7.63\% N. ${ }^{1} \mathrm{H}-\mathrm{NMR}\left(\mathrm{D}_{2} \mathrm{O}, \mathrm{ppm}\right): \delta 0.84\left(\mathrm{~d}, 6 \mathrm{H},\left(\mathrm{CH}_{3}\right)_{2} \mathrm{CH}, \mathrm{J}=6.6 \mathrm{~Hz}\right), 1.2-2.0(\mathrm{~m}, 10 \mathrm{H}$, $\left.\left(\mathrm{CH}_{2}\right)_{3}, \mathrm{CH}_{3} \mathrm{CH}, \mathrm{CH}\left(\mathrm{CH}_{3}\right)_{2}\right), 2.45\left(\mathrm{~d}, 2 \mathrm{H}, \mathrm{CH}_{2} \mathrm{Ar}, \mathrm{J}=6.9 \mathrm{~Hz}\right), 2.97\left(\mathrm{t}, 2 \mathrm{H}, \mathrm{CH}_{2} \mathrm{~N}, \mathrm{~J}=7.2 \mathrm{~Hz}\right), 3.4-3.8$ (m, 2H, CHN, CHAr), 7.0-7.4 (m, 4H, ArH).

(RS,S)-11: Calculated for $\mathrm{C}_{19} \mathrm{H}_{32} \mathrm{~N}_{2} \mathrm{O}_{4} .0 .5 \mathrm{H}_{2} \mathrm{O}: 63.13 \% \mathrm{C}, 9.20 \% \mathrm{H}, 7.75 \% \mathrm{~N}$; found: $63.34 \% \mathrm{C}$, $8.84 \% \mathrm{H}, 7.73 \%$ N. ${ }^{1} \mathrm{H}-\mathrm{NMR}\left(\mathrm{D}_{2} \mathrm{O}, \mathrm{ppm}\right): \delta 0.85\left(\mathrm{~d}, 6 \mathrm{H},\left(\mathrm{CH}_{3}\right)_{2} \mathrm{CH}, \mathrm{J}=6.6 \mathrm{~Hz}\right), 1.2-2.0(\mathrm{~m}, 10 \mathrm{H}$, $\left.\left(\mathrm{CH}_{2}\right)_{3}, \mathrm{CH}_{3} \mathrm{CH}, \mathrm{CH}\left(\mathrm{CH}_{3}\right)_{2}\right), 2.45\left(\mathrm{~d}, 2 \mathrm{H}, \mathrm{CH}_{2} \mathrm{Ar}, \mathrm{J}=7.1 \mathrm{~Hz}\right), 2.99\left(\mathrm{t}, 2 \mathrm{H}, \mathrm{CH}_{2} \mathrm{~N}, \mathrm{~J}=7.6 \mathrm{~Hz}\right), 3.4-3.8$ (m, 2H, CHN, CHAr), 7.0-7.4 (m, 4H, ArH).

\section{(S)-1-Benzyloxymethyl)propylamine ibuprofenate 12}

(S,S)-12: Calculated for $\mathrm{C}_{24} \mathrm{H}_{35} \mathrm{NO}_{3}: 74.77 \% \mathrm{C}, 9.15 \% \mathrm{H}, 3.63 \% \mathrm{~N}$; found: $74.58 \% \mathrm{C}, 9.17 \% \mathrm{H}$, $3.58 \%$ N. IR $\left(\mathrm{KBr}, \mathrm{cm}^{-1}\right)$ : v 3100-2500, $2190(\mathrm{NH}), 1640,1550,1520(\mathrm{C}=\mathrm{O}), 1100(\mathrm{C}-\mathrm{O}) .{ }^{1} \mathrm{H}-$ NMR $\left(\mathrm{CDCl}_{3}, \mathrm{ppm}\right): \delta 0.7-1.0\left(\mathrm{~m}, 9 \mathrm{H},\left(\mathrm{CH}_{3}\right)_{2} \mathrm{CH}, \mathrm{CH}_{3} \mathrm{CH}_{2}\right), 1.2-1.6\left(\mathrm{~m}, 5 \mathrm{H}, \mathrm{CH}_{2} \mathrm{CH}_{3}, \mathrm{CH}_{3} \mathrm{CHCO}\right)$ 1.6-2.0 (m, 1H, $\left.\mathrm{CH}\left(\mathrm{CH}_{3}\right)_{2}\right), 2.40\left(\mathrm{~d}, 2 \mathrm{H}, \mathrm{CH}_{2} \mathrm{CH}\left(\mathrm{CH}_{3}\right)_{2}, \mathrm{~J}=7.0 \mathrm{~Hz}\right) 2.8-3.1(\mathrm{~m}, 1 \mathrm{H}, \mathrm{CHN}), 3.1-3.7$ $\left(\mathrm{m}, 3 \mathrm{H}, \mathrm{CHCO}, \mathrm{OCH}_{2} \mathrm{CH}\right), 4.46\left(\mathrm{~s}, 2 \mathrm{H}, \mathrm{OCH}_{2} \mathrm{Ar}\right), 5.43\left(\mathrm{~S}, 3 \mathrm{H}, \mathrm{NH} \mathrm{H}^{+}\right), 6.9-7.5(\mathrm{~m}, 9 \mathrm{H}, \mathrm{ArH})$.

(RS,S)-12: Calculated for $\mathrm{C}_{24} \mathrm{H}_{35} \mathrm{NO}_{3}: 74.77 \% \mathrm{C}, 9.15 \% \mathrm{H}, 3.63 \% \mathrm{~N}$; found: $74.55 \% \mathrm{C}, 9.16 \% \mathrm{H}$, $3.60 \%$ N. IR $\left(\mathrm{KBr}, \mathrm{cm}^{-1}\right)$ : v 3100-2200, $2100(\mathrm{NH}), 1630,1550,1530(\mathrm{C}=\mathrm{O}) .{ }^{1} \mathrm{H}-\mathrm{NMR}\left(\mathrm{CDCl}_{3}\right.$, ppm): $\delta$ 0.7-1.0 (m, 9H, $\left.\left(\mathrm{CH}_{3}\right)_{2} \mathrm{CH}, \mathrm{CH}_{3} \mathrm{CH}_{2}\right), 1.2-1.5\left(\mathrm{~m}, 5 \mathrm{H}, \mathrm{CH}_{2} \mathrm{CH}_{3}, \mathrm{CH}_{3} \mathrm{CHCO}\right) 1.6-1.9(\mathrm{~m}$, $\left.1 \mathrm{H}, \mathrm{CH}\left(\mathrm{CH}_{3}\right)_{2}\right), 2.40\left(\mathrm{~d}, 2 \mathrm{H}, \mathrm{CH}_{2} \mathrm{CH}\left(\mathrm{CH}_{3}\right)_{2}, \mathrm{~J}=7.0 \mathrm{~Hz}\right) 2.8-3.0(\mathrm{~m}, 1 \mathrm{H}, \mathrm{CHN}), 3.1-3.7(\mathrm{~m}, 3 \mathrm{H}$, $\left.\mathrm{CHCO}, \mathrm{OCH}_{2} \mathrm{CH}\right), 4.46\left(\mathrm{~s}, 2 \mathrm{H}, \mathrm{OCH}_{2} \mathrm{Ar}\right), 5.84\left(\mathrm{~S}, 3 \mathrm{H}, \mathrm{NH}_{3}{ }^{+}\right), 6.9-7.5(\mathrm{~m}, 9 \mathrm{H}, \mathrm{Ar} H)$.

\section{(-)-Ephedrine ibuprofenate 13}

(S,(-))-13: Calculated for $\mathrm{C}_{23} \mathrm{H}_{34} \mathrm{NO}_{3}: 74.16 \% \mathrm{C}, 9.20 \% \mathrm{H}, 3.76 \% \mathrm{~N}$; found: $74.56 \% \mathrm{C}, 9.06 \%$ $\mathrm{H}, 3.86 \%$ N. IR $\left(\mathrm{KBr}, \mathrm{cm}^{-1}\right): \vee 3500-2000(\mathrm{OH}, \mathrm{NH}), 1580-1560(\mathrm{C}=\mathrm{O}) .{ }^{1} \mathrm{H}-\mathrm{NMR}\left(\mathrm{CDCl}_{3}, \mathrm{ppm}\right)$ : $\delta 0.83\left(\mathrm{~d}, 6 \mathrm{H},\left(\mathrm{CH}_{3}\right)_{2} \mathrm{CH}, \mathrm{J}=6.4 \mathrm{~Hz}\right), 0.86\left(\mathrm{~d}, 3 \mathrm{H}, \mathrm{CH}_{3} \mathrm{CHN}, \mathrm{J}=6.6 \mathrm{~Hz}\right), 1.41\left(\mathrm{~d}, 3 \mathrm{H}, \mathrm{CH}_{3} \mathrm{CHCO}\right.$, $\mathrm{J}=7.1 \mathrm{~Hz}), 1.5-1.9\left(\mathrm{~m}, 1 \mathrm{H}, \mathrm{CHCH}_{2}\right), 2.28\left(\mathrm{~s}, 3 \mathrm{H}, \mathrm{CH}_{3} \mathrm{~N}\right), 2.37\left(\mathrm{~d}, 2 \mathrm{H}, \mathrm{CH}_{2}, \mathrm{~J}=7.1 \mathrm{~Hz}\right), 2.76(\mathrm{dq}, 1 \mathrm{H}$, 
$\mathrm{CHN}, \mathrm{J}=6.6,1.7 \mathrm{~Hz}), 3.55(\mathrm{q}, 1 \mathrm{H}, \mathrm{CHCO}, \mathrm{J}=7.1 \mathrm{~Hz}), 5.06(\mathrm{~d}, 1 \mathrm{H}, \mathrm{CHOH}, \mathrm{J}=1.7 \mathrm{~Hz})), 6.9-7.4(\mathrm{~m}$, 9H, $\mathrm{Ar} H), 7.6\left(\mathrm{~s}, 3 \mathrm{H}, \mathrm{NH}_{2}^{+}, \mathrm{OH}\right)$.

(RS,(-))-13: Calculated for $\mathrm{C}_{23} \mathrm{H}_{34} \mathrm{NO}_{3}: 74.16 \% \mathrm{C}, 9.20 \% \mathrm{H}, 3.76 \% \mathrm{~N}$; found: $74.08 \% \mathrm{C}, 8.89 \%$ $\mathrm{H}, 3.76 \%$ N. IR (KBr, cm $\left.{ }^{-1}\right): v 3500-2100(\mathrm{OH}, \mathrm{NH}), 2490(\mathrm{NH}), 1560(\mathrm{C}=\mathrm{O}) .{ }^{1} \mathrm{H}-\mathrm{NMR}\left(\mathrm{CDCl}_{3}\right.$, ppm): $\delta 0.83\left(\mathrm{~d}, 6 \mathrm{H},\left(\mathrm{CH}_{3}\right)_{2} \mathrm{CH}, \mathrm{J}=6.4 \mathrm{~Hz}\right), 0.86\left(\mathrm{~d}, 3 \mathrm{H}, \mathrm{CH}_{3} \mathrm{CHN}, \mathrm{J}=6.6 \mathrm{~Hz}\right), 1.39\left(\mathrm{~d}, 3 \mathrm{H}, \mathrm{CH}_{3} \mathrm{CHCO}\right.$, $\mathrm{J}=7.1 \mathrm{~Hz}), 1.5-1.9\left(\mathrm{~m}, 1 \mathrm{H}, \mathrm{CHCH}_{2}\right), 2.24\left(\mathrm{~s}, 3 \mathrm{H}, \mathrm{CH}_{3} \mathrm{~N}\right), 2.35\left(\mathrm{~d}, 2 \mathrm{H}, \mathrm{CH}_{2}, \mathrm{~J}=7.1 \mathrm{~Hz}\right), 2.76(\mathrm{dq}, 1 \mathrm{H}$, $\mathrm{CHN}, \mathrm{J}=6.6,1.7 \mathrm{~Hz}), 3.52(\mathrm{q}, 1 \mathrm{H}, \mathrm{CHCO}, \mathrm{J}=7.1 \mathrm{~Hz}), 5.07(\mathrm{~d}, 1 \mathrm{H}, \mathrm{CHOH}, \mathrm{J}=1.7 \mathrm{~Hz})$ ), 6.9-7.4 (m, $9 \mathrm{H}, \mathrm{Ar} H), 8.2\left(\mathrm{~s}, 3 \mathrm{H}, \mathrm{NH}_{2}{ }^{+}, \mathrm{OH}\right)$.

\section{(R)-I-Phenyl-2-p-tolylethylamine ibuprofenate 14}

$(\mathrm{S}, \mathrm{R})-14:[\alpha]_{\mathrm{D}}{ }^{25}+70.9$ (ethanol, $\mathrm{c}=1.0$ ). Calculated for $\mathrm{C}_{28} \mathrm{H}_{35} \mathrm{NO}_{2}: 80.54 \% \mathrm{C}, 8.45 \% \mathrm{H}, 3.35 \% \mathrm{~N}$; found: $80.30 \% \mathrm{C}, 8.41 \% \mathrm{H}, 3.42 \% \mathrm{~N}$. IR $\left(\mathrm{KBr}, \mathrm{cm}^{-1}\right): \vee 3200-2300(\mathrm{NH}), 1625(\mathrm{C}=\mathrm{O}) .{ }^{1} \mathrm{H}-\mathrm{NMR}$ $\left(\mathrm{CDCl}_{3}, \mathrm{ppm}\right): \delta 0.89\left(\mathrm{~d}, 6 \mathrm{H},\left(\mathrm{CH}_{3}\right)_{2} \mathrm{CH}, \mathrm{J}=6.0 \mathrm{~Hz}\right), 1.47\left(\mathrm{~d}, 3 \mathrm{H}, \mathrm{CH} \mathrm{CHCO}_{3} \mathrm{~J}=7.1 \mathrm{~Hz}\right), 1.6-2.0$ (m, 1H, CH(CH3) $)_{2}$, 2.31 (s, 3H, $\left.\mathrm{CH}_{3} \mathrm{Ar}\right), 2.44$ (d, 2H, $\left.\mathrm{CH}_{2} \mathrm{CH}\left(\mathrm{CH}_{3}\right)_{2}, \mathrm{~J}=7.0 \mathrm{~Hz}\right), 2.8-3.0(\mathrm{~m}, 2 \mathrm{H}$, $\mathrm{CH}_{2} \mathrm{CHN}$ ), $3.65(\mathrm{q}, 1 \mathrm{H}, \mathrm{CHCO}, \mathrm{J}=7.1 \mathrm{~Hz}), 4.14$ (dd, $1 \mathrm{H}, \mathrm{CHN}, \mathrm{J}=7.8,8.0 \mathrm{~Hz}$ ), $5.16\left(\mathrm{~s}, 3 \mathrm{H}, \mathrm{NH}_{3}{ }^{+}\right.$), 7.0-7.4 (m, 13H, ArH, .

$(\mathrm{R}, \mathrm{R})-14:[\alpha]_{\mathrm{D}}{ }^{25}+27.3$ (ethanol, $\mathrm{c}=0.3$ ). Calculated for $\mathrm{C}_{28} \mathrm{H}_{35} \mathrm{NO}_{2}: 80.54 \% \mathrm{C}, 8.45 \% \mathrm{H}, 3.35 \% \mathrm{~N}$; found: $79.83 \% \mathrm{C}, 8.29 \% \mathrm{H}, 3.51 \% \mathrm{~N}$. IR $\left(\mathrm{KBr}, \mathrm{cm}^{-1}\right): \vee 3200-2300,2200-2100(\mathrm{NH}), 1615(\mathrm{C}=\mathrm{O})$. ${ }^{1} \mathrm{H}-\mathrm{NMR}\left(\mathrm{CDCl}_{3}, \mathrm{ppm}\right): \delta 0.88\left(\mathrm{~d}, 6 \mathrm{H},\left(\mathrm{CH}_{3}\right)_{2} \mathrm{CH}, \mathrm{J}=6.5 \mathrm{~Hz}\right), 1.43\left(\mathrm{~d}, 3 \mathrm{H}, \mathrm{CH}_{3} \mathrm{CHCO}, \mathrm{J}=7.1 \mathrm{~Hz}\right)$, 1.6-2.0 (m, 1H, CH( $\left.\left.\mathrm{CH}_{3}\right)_{2}\right), 2.30\left(\mathrm{~s}, 3 \mathrm{H}, \mathrm{CH}_{3} \mathrm{Ar}\right), 2.42\left(\mathrm{~d}, 2 \mathrm{H}, \mathrm{CH}_{2} \mathrm{CH}\left(\mathrm{CH}_{3}\right)_{2}, \mathrm{~J}=7.1 \mathrm{~Hz}\right), 2.8-3.0$ $\left(\mathrm{m}, 2 \mathrm{H}, \mathrm{CH}_{2} \mathrm{CHN}\right), 3.60(\mathrm{q}, 1 \mathrm{H}, \mathrm{CHCO}, \mathrm{J}=7.2 \mathrm{~Hz}$ ), 4.12 (dd, $1 \mathrm{H}, \mathrm{CHN}, \mathrm{J}=7.8,7.8 \mathrm{~Hz}), 5.17(\mathrm{~s}, 3 \mathrm{H}$, $\left.\mathrm{NH}_{3}^{+}\right), 6.9-7.4(\mathrm{~m}, 13 \mathrm{H}, \mathrm{Ar} H$,$) .$

(RS,R)-14: Calculated for $\mathrm{C}_{28} \mathrm{H}_{35} \mathrm{NO}_{2}: 80.54 \% \mathrm{C}, 8.45 \% \mathrm{H}, 3.35 \% \mathrm{~N}$; found: $80.61 \% \mathrm{C}, 8.41 \%$ $\mathrm{H}, 3.42 \%$ N. IR $\left(\mathrm{KBr}, \mathrm{cm}^{-1}\right): \vee 3200-2300,2200-2100(\mathrm{NH}), 1620(\mathrm{C}=\mathrm{O}) .{ }^{1} \mathrm{H}-\mathrm{NMR}$ was identical to $(\mathrm{S}, \mathrm{R})-$ and $(\mathrm{R}, \mathrm{R})-19$.

\section{(S)-Phenylglycinol ibuprofenate 15}

(S,S)-15: Calculated for $\mathrm{C}_{21} \mathrm{H}_{29} \mathrm{NO}_{3}: 73.44 \% \mathrm{C}, 8.51 \% \mathrm{H}, 4.08 \% \mathrm{~N}$; found: $73.29 \% \mathrm{C}, 8.50 \%$ $\mathrm{H}, 4.25 \% \mathrm{~N}$. IR $\left(\mathrm{KBr}, \mathrm{cm}^{-1}\right): \vee 3500-2200,2180(\mathrm{OH}, \mathrm{NH}), 1640,1550-1520(\mathrm{C}=\mathrm{O}) .{ }^{1} \mathrm{H}-\mathrm{NMR}$ $\left(\mathrm{CDCl}_{3}, \mathrm{ppm}\right): \delta 0.88\left(\mathrm{~d}, 6 \mathrm{H},\left(\mathrm{CH}_{3}\right)_{2} \mathrm{CH}, \mathrm{J}=6.7 \mathrm{~Hz}\right), 1.45\left(\mathrm{~d}, 3 \mathrm{H}, \mathrm{CH}_{3} \mathrm{CHCO}, \mathrm{J}=7.1 \mathrm{~Hz}\right), 1.6-2.0(\mathrm{~m}$, $\left.1 \mathrm{H}, \mathrm{CHCH}_{2}\right), 2.42\left(\mathrm{~d}, 2 \mathrm{H}, \mathrm{CH}_{2} \mathrm{Ar}, \mathrm{J}=7.1 \mathrm{~Hz}\right), 3.4-3.8\left(\mathrm{~m}, 3 \mathrm{H}, \mathrm{CH}_{2} \mathrm{OH}, \mathrm{CHCO}\right), 4.10(\mathrm{dd}, 1 \mathrm{H}, \mathrm{CHN}$, $\mathrm{J}=8.5,4.3 \mathrm{~Hz}), 4.76\left(\mathrm{~s}, 4 \mathrm{H}, \mathrm{OH}, \mathrm{NH}_{3}{ }^{+}\right), 6.9-7.5(\mathrm{~m}, 9 \mathrm{H}, \mathrm{Ar} H)$.

(RS,S)-15: Calculated for $\mathrm{C}_{21} \mathrm{H}_{29} \mathrm{NO}_{3}: 73.44 \% \mathrm{C}, 8.51 \% \mathrm{H}, 4.08 \% \mathrm{~N}$; found: $72.85 \% \mathrm{C}, 8.37 \%$ $\mathrm{H}, 4.06 \% \mathrm{~N}$. IR $\left(\mathrm{KBr}, \mathrm{cm}^{-1}\right): \vee 3500-2200,2160(\mathrm{OH}, \mathrm{NH}), 1660,1550(\mathrm{C}=\mathrm{O}) .{ }^{1} \mathrm{H}-\mathrm{NMR}\left(\mathrm{CDCl}_{3}\right.$, ppm): $\delta 0.89\left(\mathrm{~d}, 6 \mathrm{H},\left(\mathrm{CH}_{3}\right)_{2} \mathrm{CH}, \mathrm{J}=6.5 \mathrm{~Hz}\right), 1.46\left(\mathrm{~d}, 3 \mathrm{H}, \mathrm{CH} \mathrm{CHCO}_{3} \mathrm{~J}=7.2 \mathrm{~Hz}\right), 1.6-2.0(\mathrm{~m}, 1 \mathrm{H}$, $\left.\mathrm{CHCH}_{2}\right), 2.43\left(\mathrm{~d}, 2 \mathrm{H}, \mathrm{CH}_{2} \mathrm{Ar}, \mathrm{J}=7.0 \mathrm{~Hz}\right), 3.5-3.8\left(\mathrm{~m}, 3 \mathrm{H}, \mathrm{CH} \mathrm{H}_{2} \mathrm{OH}, \mathrm{CHCO}\right), 4.11$ (dd, $1 \mathrm{H}, \mathrm{CHN}$, $\mathrm{J}=8.5,4.2 \mathrm{~Hz}), 4.76\left(\mathrm{~s}, 4 \mathrm{H}, \mathrm{OH}, \mathrm{NH}_{3}{ }^{+}\right), 6.9-7.5(\mathrm{~m}, 9 \mathrm{H}, \mathrm{Ar} H)$.

\section{Resolution of ibuprofen 1 by $(S)$-phenylglycinol $(S)-7$}

Racemic ibuprofen (RS)-1 (0.5 g, $2.4 \mathrm{mmol})$ and (S)-phenylglycinol (S)-7 (0.33 g, $2.4 \mathrm{mmol})$ were dissolved in hot acetone $(5 \mathrm{ml})$ or a hot mixture of toluene:hexane $=2: 1(\mathrm{v} / \mathrm{v})$ and gradually cooled. The formed crystalline salt (S,S)-15 was filtered off, washed with cold solvent, dried in vacuo and weighed. A fraction of the salt was hydrolyzed and the ee of liberated ibuprofen 1 was analyzed by chiral HPLC. Results: acetone as solvent: $0.52 \mathrm{~g}(1.5 \mathrm{mmol}, 63 \%), 39.4 \% \mathrm{de}, \mathrm{S}=0.50$; toluene:hexane $=2: 1$ (v/v) as solvent: $0.60 \mathrm{~g}(1.8 \mathrm{mmol}, 73 \%), 37 \% \mathrm{de}, \mathrm{S}=0.54$.

\section{(-)-N-Methylephedrine mandelate 20}

$(\mathrm{S},(-))-20:[\alpha]_{\mathrm{D}}{ }^{25}+24.6$ (ethanol, $\mathrm{c}=1.0$ ). Calculated for $\mathrm{C}_{19} \mathrm{H}_{25} \mathrm{NO}_{4}: 68.86 \% \mathrm{C}, 7.60 \% \mathrm{H}, 4.23 \%$ $\mathrm{N}$; found: $68.59 \% \mathrm{C}, 7.55 \% \mathrm{H}, 4.26 \% \mathrm{~N}$. IR $\left(\mathrm{KBr}, \mathrm{cm}^{-1}\right): \vee 3500-3000(\mathrm{OH}), 3000-2100(\mathrm{NH})$, $1600(\mathrm{C}=\mathrm{O})$. ${ }^{\mathrm{H}} \mathrm{H}-\mathrm{NMR}\left(\mathrm{CDCl}_{3}, \mathrm{ppm}\right): \delta 1.00\left(\mathrm{~d}, 3 \mathrm{H}, \mathrm{CH}_{3} \mathrm{CH}, \mathrm{J}=6.9 \mathrm{~Hz}\right), 2.67\left(\mathrm{~s}, 6 \mathrm{H}, \mathrm{N}\left(\mathrm{CH}_{3}\right)_{2}\right)$, 
$3.14\left(\mathrm{dq}, 1 \mathrm{H}, \mathrm{CHCH}_{3}, \mathrm{~J}=2.1,6.9 \mathrm{~Hz}\right), 4.97(\mathrm{~s}, 1 \mathrm{H}, \mathrm{CHCO}), 5.41(\mathrm{~d}, 1 \mathrm{H}, \mathrm{CHO}, \mathrm{J}=2.1 \mathrm{~Hz})$ ), 7.0-7.5 (m, 13H, $\left.\mathrm{Ar} H, \mathrm{~N} H^{+}, 2 \mathrm{OH}\right)$.

$(\mathrm{R},(-))-20:[\alpha]_{\mathrm{D}}^{25}+65.8$ (ethanol, $\mathrm{c}=1.0$ ). Calculated for $\mathrm{C}_{19} \mathrm{H}_{25} \mathrm{NO}_{4}: 68.86 \% \mathrm{C}, 7.60 \% \mathrm{H}, 4.23 \%$ $\mathrm{N}$; found: $68.67 \% \mathrm{C}, 7.61 \% \mathrm{H}, 4.25 \% \mathrm{~N}$. IR $\left(\mathrm{KBr}, \mathrm{cm}^{-1}\right): v 3500(\mathrm{OH}), 3400-2200(\mathrm{NH}), 1600$ $(\mathrm{C}=\mathrm{O}) .{ }^{1} \mathrm{H}-\mathrm{NMR}\left(\mathrm{CDCl}_{3}, \mathrm{ppm}\right): \delta 1.00\left(\mathrm{~d}, 3 \mathrm{H}, \mathrm{CH} \mathrm{CH}_{3} \mathrm{CH}=7.1 \mathrm{~Hz}\right), 2.70\left(\mathrm{~s}, 6 \mathrm{H}, \mathrm{N}\left(\mathrm{CH}_{3}\right)_{2}\right), 3.12$ (dq, $\left.1 \mathrm{H}, \mathrm{CHCH}_{3}, \mathrm{~J}=2.0,7.1 \mathrm{~Hz}\right), 4.94(\mathrm{~s}, 1 \mathrm{H}, \mathrm{CHCO}), 5.36(\mathrm{~d}, 1 \mathrm{H}, \mathrm{CHO}, \mathrm{J}=2.1 \mathrm{~Hz}), 7.0-7.5(\mathrm{~m}, 13 \mathrm{H}$, $\left.\mathrm{Ar} H, \mathrm{~N} H^{+}, 2 \mathrm{OH}\right)$.

(RS,(-))-20: Calculated for $\mathrm{C}_{19} \mathrm{H}_{25} \mathrm{NO}_{4}: 68.86 \% \mathrm{C}, 7.60 \% \mathrm{H}, 4.23 \% \mathrm{~N}$; found: $68.49 \% \mathrm{C}, 7.58 \%$ $\mathrm{H}, 4.26 \%$ N. IR $\left(\mathrm{KBr}, \mathrm{cm}^{-1}\right)$ : v 3500-3000 (OH), 3000-2100(NH), $1600(\mathrm{C}=\mathrm{O}) .{ }^{1} \mathrm{H}-\mathrm{NMR}\left(\mathrm{CDCl}_{3}\right.$, ppm): $\delta 1.00\left(\mathrm{~d}, 3 \mathrm{H}, \mathrm{CH}_{3} \mathrm{CH}, \mathrm{J}=6.7 \mathrm{~Hz}\right), 2.69\left(\mathrm{~s}, 6 \mathrm{H}, \mathrm{N}\left(\mathrm{CH}_{3}\right)_{2}\right), 3.13\left(\mathrm{dq}, 1 \mathrm{H}, \mathrm{CHCH}_{3}, \mathrm{~J}=2.0,6.7\right.$ $\mathrm{Hz}), 4.96(\mathrm{~s}, 1 \mathrm{H}, \mathrm{CHCO}), 5.39$ (d, $1 \mathrm{H}, \mathrm{CHO}, \mathrm{J}=2.0 \mathrm{~Hz}), 7.0-7.5\left(\mathrm{~m}, 13 \mathrm{H}, \mathrm{ArH}, \mathrm{N} H^{+}, 2 \mathrm{OH}\right)$.

(+)-(2S,3R)-4-Dimethylamino-3-methyl-1,2-diphenyl-2-butanol mandelate 21

$(\mathrm{S},(+))-21:[\alpha]_{\mathrm{D}}{ }^{25}+47.8$ (ethanol, $\mathrm{c}=1.0$ ). Calculated for $\mathrm{C}_{27} \mathrm{H}_{33} \mathrm{NO}_{4}: 74.76 \% \mathrm{C}, 7.64 \% \mathrm{H}, 3.22 \%$ $\mathrm{N}$; found: $74.36 \% \mathrm{C}, 7.58 \% \mathrm{H}, 3.23 \% \mathrm{~N}$. FTIR $\left(\mathrm{KBr}, \mathrm{cm}^{-1}\right): \vee 3500-3000,3401,3162(\mathrm{OH})$, 3000-2000, 2640, $2400(\mathrm{NH}), 1617(\mathrm{C}=\mathrm{O}) .{ }^{1} \mathrm{H}-\mathrm{NMR}\left(\mathrm{CDCl}_{3}, \mathrm{ppm}\right): \delta 0.96\left(\mathrm{~d}, 3 \mathrm{H}, \mathrm{CH} \mathrm{CH}_{3} \mathrm{~J}=6.7\right.$ $\mathrm{Hz}), 1.9-2.8\left(\mathrm{~m}, 3 \mathrm{H}, \mathrm{CHCH}_{3}, \mathrm{CH}_{2} \mathrm{Ar}\right), 2.40\left(\mathrm{~s}, 6 \mathrm{H}, \mathrm{N}\left(\mathrm{CH}_{3}\right)_{2}\right), 3.0-3.4\left(\mathrm{~m}, 2 \mathrm{H}, \mathrm{CH}_{2} \mathrm{~N}\right), 4.96(\mathrm{~s}, 1 \mathrm{H}$, $\mathrm{CHO}), 7.0-7.6(\mathrm{~m}, 15 \mathrm{H}, \mathrm{Ar} H), 8.06\left(\mathrm{~s}, 3 \mathrm{H}, \mathrm{N} H^{+}, 2 \mathrm{OH}\right)$.

$(\mathrm{R},(+))-21:[\alpha]_{D}{ }^{25}-28.9$ (ethanol, $c=1.0$ ). Calculated for $\mathrm{C}_{27} \mathrm{H}_{33} \mathrm{NO}_{4}: 74.76 \% \mathrm{C}, 7.64 \% \mathrm{H}, 3.22 \%$ $\mathrm{N}$; found: $74.36 \% \mathrm{C}, 7.59 \% \mathrm{H}, 3.23 \% \mathrm{~N}$. FTIR $\left(\mathrm{KBr}, \mathrm{cm}^{-1}\right): \vee 3500-3000,3372,3244(\mathrm{OH})$, 3000-2000 (NH), $1623(\mathrm{C}=\mathrm{O}){ }^{1} \mathrm{H}-\mathrm{NMR}\left(\mathrm{CDCl}_{3}, \mathrm{ppm}\right): \delta 0.95\left(\mathrm{~d}, 3 \mathrm{H}, \mathrm{CH}{ }_{3} \mathrm{CH}, \mathrm{J}=6.5 \mathrm{~Hz}\right), 1.9-2.9$ (m, 3H, $\left.\mathrm{CHCH}_{3}, \mathrm{CH}_{2} \mathrm{Ar}\right), 2.40\left(\mathrm{~s}, 6 \mathrm{H}, \mathrm{N}\left(\mathrm{CH}_{3}\right)_{2}\right), 3.0-3.4\left(\mathrm{~m}, 2 \mathrm{H}, \mathrm{CH}_{2} \mathrm{~N}\right), 4.96(\mathrm{~s}, 1 \mathrm{H}, \mathrm{CHO}), 6.28$ (s, 3H, $\left.\mathrm{NH}^{+}, 2 \mathrm{OH}\right), 7.0-7.6(\mathrm{~m}, 15 \mathrm{H}, \mathrm{Ar} H)$.

(RS,(+))-21: Calculated for $\mathrm{C}_{27} \mathrm{H}_{33} \mathrm{NO}_{4}: 74.76 \% \mathrm{C}, 7.64 \% \mathrm{H}, 3.22 \% \mathrm{~N}$; found: $74.36 \% \mathrm{C}, 7.58 \%$ $\mathrm{H}, 3.23 \%$ N. FTIR (KBr, cm $\left.{ }^{-1}\right)$ : $v$ 3500-3000, 3372, $3164(\mathrm{OH}), 3000-2100(\mathrm{NH}), 1617(\mathrm{C}=\mathrm{O})$. ${ }^{1} \mathrm{H}-\mathrm{NMR}\left(\mathrm{CDCl}_{3}, \mathrm{ppm}\right): \delta 0.97\left(\mathrm{~d}, 3 \mathrm{H}, \mathrm{CH}_{3} \mathrm{CH}, \mathrm{J}=6.5 \mathrm{~Hz}\right), 1.9-2.9\left(\mathrm{~m}, 3 \mathrm{H}, \mathrm{CHCH}_{3}, \mathrm{CH}_{2} \mathrm{Ar}\right), 2.41$ $\left(\mathrm{s}, 6 \mathrm{H}, \mathrm{N}\left(\mathrm{CH}_{3}\right)_{2}\right), 3.0-3.4\left(\mathrm{~m}, 2 \mathrm{H}, \mathrm{CH}_{2} \mathrm{~N}\right), 4.96(\mathrm{~s}, 1 \mathrm{H}, \mathrm{CHO}), 6.65\left(\mathrm{~s}, 3 \mathrm{H}, \mathrm{N} H^{+}, 2 \mathrm{OH}\right), 7.1-7.5(\mathrm{~m}$, 15H, ArH).

\section{References}

1. a) Van der Haest, A. D.; Wijnberg, H.; Leusen, F. J. J.; Bruggink, A. Recl. Trav. Chim. Pays-Bas 1990, 109, 523. b) Leusen, F. J. J. Rationalization of Racemate Resolution: A Molecular Modelling Study; Ph.D. Thesis: University of Nijmegen, The Netherlands, 1993. c) Van der Haest, A. D. Classical Resolutions; Design of Resolving Agents and Studies of Diastereomeric Salts; Ph.D. Thesis: University of Groningen, The Netherlands, 1992.

2. Kozma, D.; Acs, M.; Fogassy, E. Tetrahedron 1994, 50, 6907 and references cited herein.

3. Kozma, D.; Pokol, G.; Acs, M. J. Chem. Soc., Perkin Trans. 2 1992, 435.

4. Jacques, J.; Collet, A.; Wilen, S. H. Enantiomers, Racemates and Resolution; John Wiley \& Sons: New York, 1981, chap. 2.2.3.

5. Fogassy, E.; Faigl, F.; Darvas, F.; Acs, M.; Toke, L. Tetrahedron Lett. 1980, 21, 2841.

6. Eliel, E. L.; Wilen, S. H. Stereochemistry of Organic Compounds; John Wiley \& Sons: New York, 1994, chap. 7.3.b.

7. a) Manimaran, T.; Impastato, F. J. US 5015764, Ethyl Corp., USA, 18-06-90; Chem. Abstr. 115:135162. b) Nicholson, J. S.; Tantum, J. G. US 4209638, 1980. c) Lukas, H.; Schuster, O.; Rau, G. US 4983765, 1991. d) WO 9315039, Ethyl Corp., USA, 18-12-92; Chem. Abstr. 119:270637.

8. a) Tung, H.; Waterson, S.; Reynolds, S. US 4994604, Merck, 10-01-90. b) Bhattacharya, A.; Fritch, J. R.; Murphy, C. D.; Zeugler, L. D.; McAdams, C. A. US 5380867, Hoechst, 19-10-93.

9. Ref. 4, chap. 2.4.8.

10. Peak-fitting was performed using PeakFit ${ }^{\circledR}$ version 4 for Win32 (Jandel Scientific Software). Pearson IV peaks were used as peak descriptors. 
11. Ref. 4, chap. 5.1.13.

12. a) Optical Resolution of Amines with Mandelic Acid; Yamakawa Technical Bulletin No. 1, Yamakawa Chemical Industry Co. Ltd: Tokyo, Japan, 1991. b) Ref. 6, pp. 329-344. c) Newman, P. Optical Resolution Procedures for Chemical Compounds; Optical Resolution Information Center: New York, 1981.

13. Sheldon, R. A. Chirotechnology, Industrial Synthesis of Optically Active Compounds; Marcel Dekker: New York, 1993; p. 156.

14. a) Ingersoll, A. W; Babcock, S. H.; Burns, F. B. J. Am. Chem. Soc. 1933, 55, 411. b) Leclerq, M.; Jaques, J. Bull. Soc. Chim. Fr. 1975, 9-10, 2052. c) Becket, A. H. Chaulis, N. H. J. Pharm. Sci. 1966, 55, 1155. d) Smith, L. J. Prakt. Chem. 84, 743. e) De Diego, H. L. Acta Chem. Scand. 1995, 49, 459. f) Larsen, S.; De Diego, H. L. Models in Chemistry 1995, 132, 441.

15. a) Stoll, A.; Preyer, J.; Hofmann, A. Helv. Chim. Acta 1943, 26, 929. b) DE 2838882, 15-03-79 (06-09-77), American Cyanamid, USA; Chem. Abstr. 90:203672

16. Acs, M.; Novotny-Bregger, E.; Simon, K.; Argay, G. J. Chem. Soc., Perkin Trans. 2 1992, 2011.

17. Kozma, D.; Nyeki, A.; Acs, M.; Fogassy, E. Tetrahedron: Asymmetry 1994, 5, 315.

18. Bergman, S. Arkiv Kemi 1926, 9, 1.

19. a) Jarowski, C.; Hartung, W. H. J. Org. Chem. 1947, 8, 564. b) Skita; Keil; Meinev, Berichte 1933, 974.

20. Kazan, J.; Chen, S. US 4259521, 31-03-81 (09-10-79), American Cyanamid, USA; Chem. Abstr. 95:6842.

21. Ref. 4, chap. 2.2.3-2.2.4.

22. Still, W. C.; Kahn, M.; Mitra, A. J. Org. Chem. 1978, 43, 2923.

23. Manimaran, T.; Stahly, G. P. Tetrahedron: Asymmetry 1993, 4, 1949.

24. Ref. 4, pp. 35-36.

25. March, J. Advanced Organic Chemistry: Reactions, Mechanisms and Structure; 4th Edn, John Wiley \& Sons: New York, 1992, pp. 386-387.

26. a) Touet, J.; Ruault, T.; Brown, E. Synth. Commun. 1994, 24, 293. b) Touet, J.; Faveriel, L.; Brown,

E. Tetrahedron Lett. 1993, 34, 2957.

27. Hyne, J. B. J. Am. Chem. Soc. 1959, 81, 6058.

(Received in UK 9 October 1997) 